\title{
Various Aspects of the Charitable Activity of Jews in Drohobych in THE Early 20Th Century
}

\author{
Katarzyna Thomas \\ e-mail: thomaskatarzyna@gmail.com
}

Keywords: charity, Drohobych, aid for children, Jews, charity associations, oil industry, Galicia

\begin{abstract}
The article describes the charitable activities of Jews in Drohobych during the Habsburg monarchy and at the beginning of the Polish state. The associations described, run predominantly by women, worked mainly for the benefit of Jewish orphans and children of impoverished families. The significant presence of Jews among the owners of oil companies largely contributed to the development of charity activities in the form of institutions meeting the needs of specific social groups.
\end{abstract}

Contemporary charitable activities take on more organized forms beyond the traditional. This type of help for the needy is evident in Drohobych at the beginning of the 20th century, as it was organized into social associations directed at helping specific social groups: children, women, students, and old people. Among the many forms, one can also distinguish individual acts of wealthy people financing charitable enterprises.

The aim of the article is to describe the forms of Jewish charity at the beginning of the 20 th century in Drohobych on the basis of collected archival information. Social changes and rapid modernization in the context of the rapidly developing oil industry posed new social challenges. Limitations on the roles of religious communities in the 19th century resulted in the emergence of new forms of charity and self-help institutions, independent of the Jewish community. The basic research question is to identify the forms of activity, target groups, and people who made up these organizations. Previous research on charity in Galicia includes many scientific papers dealing with charity in many aspects, although no work has so far been written describing this issue in relation to Drohobych. ${ }^{1}$

As the article is intended to refer to Galician times, it will only consider the years leading up to 1918. For this reason, the activities of associations and individual foundation acts are described under the restrictions of these times, with some exceptions. The author decided to go beyond the time frame in those aspects of charity which originated in the Galician period and continued to develop in the later historical period, in order to fully reflect the nature of the described charity activities, due to the limited archival material which forms the basis for consideration. The author analyzed the archival sources based on documents of the State Archives of Lviv Oblast. It should be noted that the documentation gathered there is very rudimentary and brief regarding the activities of

\footnotetext{
${ }^{1}$ Broński 2008; Meissner 2002; Domańska 2011.
} 
individual charity associations. In most cases, a statute and its copies remain the only documents confirming the existence of a charity. This unfortunately does not allow the historian to make a full analysis of the activities and location of the association at a specific time. Based on the literature on the subject and the magazine, the author attempted to trace the charitable activities of Drohobych Jews at the beginning of the 20th century, not with the intention of presenting the entire spectrum of the subject of charity in Drohobych at the beginning of the 20th century, but only the most important initiatives serving the community.

Drohobych is a unique city known for its outstanding artists, military officers, and scientists. ${ }^{2}$ Currently, it is mainly associated with the work of Bruno Schulz, who made his hometown famous covering other aspects of the city's history. Socio-economic changes over the last two centuries have made the city and its people a very interesting subject of historical research. Until the nineteenth century, Drohobych was known only for the mining of salt, and did not otherwise stand out in any particular way compared to the surrounding cities and towns of Lviv Province. In addition to salt, local residents used the oil flowing out of the ground, called kipiaczka, to soak hides and grease carts. ${ }^{3}$ In the nineteenth century, industrial applications of oil were discovered. ${ }^{4}$ The history of refining kerosene plays an important role in the history of Drohobych, including its Jewish inhabitants. It was a breakthrough moment for Drohobych, as it transformed from a nondescript sleepy city to the capital of the oil basin. It also gained another infamous name, the vestibule of the "Galician hell" which was the town of Boryslav. ${ }^{5}$ Due to the rapid development of the oil industry, the demand for foreign articles, culture, print media and prostitution increased. The remains of this prosperous period are stately buildings, especially the houses and villas of oil entrepreneurs, the local elite. The overall situation of Eastern Galicia had an impact on the material status of the local population. ${ }^{6}$

2 Mozes Efraim Lilien, Leon Sternbach, Herman Lieberman and the Gottlieb brothers were born in Drohobych. Polski Słownik Judaistyczny 2003: 48, 50, 511-512, 578.

3 Pollack 2007: 37.

${ }^{4}$ It was only the actions of the saline controller Józef Hecker, who, along with Jan Mitis, at the beginning of the 19th century experimentally distilled this kipiaczka and obtained glowing oil. This breakthrough invention quickly found a useful application, because as early as 1817 it was lighting the streets of Drohobych. Orders for this innovative way of lighting were made by Czech Prague and Vienna, although the problems with completing the order nullified the extraordinary discovery. Further experiments were undertaken by two Jews, Abraham Schreiner and Leib Stierman, but their actions brought mainly legal problems to Schreiner, so he abandoned the occupation and went to Lviv and sold the results at Mikolasch's Pharmacy. There, Ignacy Łukasiewicz and Jan Zeh made the final fractional distillation of crude oil, which became the beginning of the oil industry in Galicia. In Drohobych itself, no oil was extracted, but here representatives of large foreign companies investing in oil had their headquarters, thanks to which the city gained an international character. On the streets Polish, Yiddish, Ukrainian, English, German and French were heard. Rosenberg 1938: 113; Frank 2005: 57; Tomanek 1928: 7-8.

${ }^{5}$ Boryslav, located near Drohobych, was the centre of extraction, oil fields contributed to the change of the city landscape and the surrounding area into a "lunar land," everything was black and grey, dirty, and clogged with purulent oil, including the streets and people; Pollack 2007: 41.

${ }^{6}$ Although the city began to develop economically and infrastructurally, the percentage of people under financial difficulties was significant. Unregulated, the emerging industry was conducive to speculation and exploitation of the unconscious value of land and investment by local people. Scribes and lawyers who conducted countless trials gained the most. In 1914, the Drohobych Regional Court was the largest in all of Austria. In the small commune of Borysław in the second half of the 19th century, 1,200 entrepreneurs operated 3,500 oil wells; Ibid.: 39 . 
The refineries owned by the Jewish families of Lauterbach, Gartenberg, Waldinger, Freilich, Feuerstein, Lieberman, Beckenroth and Schreier ${ }^{7}$ constituted an important part of the great oil industry, which is important in the context of charity, as among the more generous donors were the Jewish families who profited from the extraction of oil. By financially supporting charitable enterprises, they contributed to the development of the community and the city.

Galicia was one of the most backward territories of the Austro-Hungarian Monarchy, as the proverbial Galician poverty affected the whole mass of society below the poverty line. Living conditions, diet, and illness meant that the average life expectancy was 27 years for men and 28.5 for women. ${ }^{8}$

Drohobych was no exception, and industrial expansion only deepened divisions. In addition to a relatively small group of industrial entrepreneurs, freelancers, and the intelligentsia, a significant part of the society was made up of people whose income did not cover their living needs. There was the Franz Josef Gymnasium in Drohobych, which could be the ticket to an education and a better life, but many students gave up education, not because of a lack of ambition but out of necessity. In poor Jewish families with many children, every pair of hands that could work and provide income to the family counted. Young people were taught a profession very quickly. This way of thinking did not change for a long time, and similar behaviours continued in the interwar period. Few managed to escape the environment and fulfil their ambitions. ${ }^{9}$

At the beginning of the 20th century, the Jewish community of Drohobych constituted the majority of Poles and Ukrainians of the town, at that time called Ruthenians. ${ }^{10}$

\footnotetext{
${ }^{7}$ In addition to the large and stable, often international, oil companies, there were a whole host of small mining societies, which were characterized by high instability: like mushrooms after rain, new companies were created, which changed dozens of times and disappeared just as quickly as they appeared, which is characteristic especially in the first period of the development of the oil industry. Imperfect mining methods and lack of knowledge in the area of oil exploration meant that one could become a millionaire or go bankrupt overnight. People from various corners came to Drohobych hoping for quick earnings. Many of the thriving companies such as L. Gartenberg, Israel Liebermann, J.B Wagman \& Co., were commonly called the "Jewish bank" and they belonged to Jews; Ibid.: 39. Vlasyslava Moskalets writes more about the connections and role of Jewish oil entrepreneurs in the development of the oil basin - Moskalets 2015: 107-115.

${ }^{8}$ Szczepanowski 1888: 24.

9 One such ambitious young person was "Kitka," born in Sambor and a resident of Drohobych, whose father, a worker at the oil refinery "Galicja," opposed his son's continuing education: "After graduating from four common classes, I went to junior high school. Joining the gymnasium was preceded by difficulties with my parents, who disagreed with my plan. My father especially wanted me to learn a profession. I also had to resort to lies, which I even liked. Two months before the end of the school year, I told my mother, for example, that there was a Jew in a wig today who was asking a teacher whether to send her son to junior high school. Namely, I wanted my mother to go to a teacher who could not advise otherwise than to recommend junior high school. After consulting with my father, who often surrenders to my mother in such matters $[\ldots]$ When I returned home that day, my parents told me that I would be able to pass, but they would not accept any help for me [...] However, I agreed to my parents' proposal, because I knew that they would not say no to me at the last minute. It was the same." This author of memoirs written for a competition organized in the 1930s by the Jewish Scientific Institute in Vilnius, received his high school diploma in Drohobycz and began his studies in Krakow; Cała 2003: 465-467.

${ }^{10}$ The first Jews appeared in the area of modern Drohobych before the charter was granted thanks to the royal Jewish official Jagiełł, who was leasing salt mines. Towards the end of the 16th century, Jews were noted in many cities and towns of Red Ruthenia, mainly as innkeepers and tavernkeepers. The Jewish quarter of Drohobycz, called Łan, was created as a result of granting the Stefan Batory privilege "de non tolerandis Judeis" from 1578. Jews who had lived so far on Żydowska Street moved near the city to the so-called
} 
For a better picture of the scale of charitable activities of the Jews from Drohobych one should refer to the general population of the city. The aspect of nationality is extremely important because for the period discussed Jews constituted the largest denominational group in Drohobych. Censuses do not allow for a thorough analysis of demographic changes, as the Austrian censuses are marked by many formal errors. Language criteria, unfortunately, are not helpful in this matter, so the most appropriate distinction is based on religion. This is not an accurate method, but in the case of Jews, where conversions were extraordinarily rare, it is enough to represent the real size of the community.

The last census in Galicia was carried out in 1910, and at that time out of the 34,665 inhabitants of Drohobych as many as 15,313 were Jews. The second most numerous group was Roman Catholic at 11,890, and third was Greek Catholic at 7,348. Other denominations did not constitute a significant social group, only numbering 114 people. The composition of Drohobych in the following years did not differ much from that of 1910, with those of the Mosaic religion at 44.2\%, Roman Catholic at 34.3\%, and Greek Catholic at $21.2 \%$. Thus, Jews constituted the most numerous group, and they seem to have been more active in the charity field.

The analysis of charity in Drohobych comes with considerable problems for the researcher into the subject. First of all, the preserved archival database is small. The documentation of charitable societies is incomplete, and in many cases information is provided only by statutes, making it impossible to precisely determine the period and scope of their activities. To a large extent, all kinds of associations approached their activities quite freely, so it can be suspected that they were more informal. It brought together people of similar values, beliefs, and professions, often associated with a specific synagogue or a house of prayer, who provided financial assistance adequate to the needs. Another source of problems of charity analysis in Drohobych lies in its diversity.

Charitable activities among the Jewish community can be divided into two types: regular, in the form of charity associations, and irregular, characterized by financial grants for specific socially useful undertakings.

The Jewish commune provided some of its help to the needy by subsidizing aid organizations or supporting charity collections. In addition, there were religious and charity associations, and here the categorization of organizations into religious and religious/ charitable is extremely difficult. When analysing the activities of these organizations, they cannot be clearly assigned to religious or charitable groups because they fulfilled both functions. On one hand, religion was the basis for establishing associations, while on the other hand, mutual financial assistance was an important element.

Further distinctions should be made among the target groups receiving assistance. In Drohobych, various forms of help were provided to poor adults, children from poor families, and orphans.

Łan Starościński. In the following centuries, despite the difficulties, the Jewish community grew systematically. In the second half of the 19th century, Jews were given the right to elect a city council. After the 1873 election, out of thirty-six members, sixteen were Jews. For the first time, a Jew in the person of Hersch Goldhammer became the vice president of the city. The Jewish community funded a hospital for poor Jews. After several dozen years of construction, in 1862 one of the largest synagogues in Central and Eastern Europe, the Choral Synagogue, also called the Great Synagogue; Schipper 1937: 105; Wikler 1969: 41; Hakehillot. Encyclopedia of Jewish Communities 1980: 160-171; Pilat 1913: 150. 
Jewish children and youth could count on a wide spectrum of help from foundations. One of the most architecturally significant organizations was the Jewish Orphanage, founded in 1913 on the initiative of a prominent inhabitant of Drohobych, Elijah Feuerstein. ${ }^{11}$ The two-story building was in Sobieski Street. The real effort of the construction was undertaken by the son of the founder, Jakub Feuerstein, who used the help of an architect, an employee of the magistrate Franciszek Jelonka, in designing the building. ${ }^{12}$ The need to create a home for children was urgent, so construction work was accelerated to accommodate needy children as soon as possible. In August, half a year before the opening, 30 needy children were brought in from Medenica, Hubicz, Boryslav, Tustanowice and Schodnica. ${ }^{13}$ The solemn dedication of the Orphans' House built on the grounds of the Jewish community at the cost of half a million crowns took place in January 1914. The ceremonies gathered the local elite, including Mayor Rajmund Jarosz, the Staroste of Żukowtyński Dr Pilecki, Deputy Marshal Pallas, members of the religious community, and the headmaster of Staromiejski Junior High School. Count Zamoyski came specially from Lviv. A choir of students accompanied by the organ sang the prayer "Matową," then Rabbi Margulies gave a speech in Polish, which concerned the essence of charity towards one's neighbour:

Speaking of charity, which is one of the pillars on which the world rests, he pointed out that this virtue brings us internal satisfaction, and at the same time is the foundation of harmony and harmony in the social world, because the progress of humanity consists in striving to equalize class differences, and whether individuals fulfil this life task, along with their religious duties. The source of moral principles is science revealed at Sinai, and the heart is the height on which God reveals himself to humanity, striving for it with the opportunity to fulfil his duties of love of neighbour. ${ }^{14}$

The ceremony ended with prayers in Polish and Hebrew and singing of a hymn in honour of Emperor Franz Joseph. The home soon fulfilled its statutory activity, but in September 1914 it was occupied by the Russian army, which used it as a military barracks. The following year, it was taken over by the Austro-Hungarian Army for use as a military hospital. It was only after the end of hostilities in 1919 that it was returned to the Jewish community. The management committee began to succumb to Zionist influence, the Hebrew language was introduced, and a Hebrew library was created. The area around the building was allocated to a farm with ten cows and two horses, the development of which was possible thanks to donations from, among others, the Drohobychan and Boryslavians Association in New York. ${ }^{15}$ The Orphans' Home supported 70 children at that time.

The Orphans' Home was maintained by a special association tasked with supporting the pupils and managing the institution: The "Society to Support the Children of the Jewish Orphans' Home" was founded in 1912. Funds for the society and the orphanage

11 The history of the orphanage in the context of the activity of Jakub Feuerstein, who aroused extreme emotions as a representative of the Jewish community, was the subject of research into the initial stages of the idea and construction of the orphanage; Лазорак 2013.

12 Mściwujewski 1929: 26.

13 "Tygodnik Drohobycki" 1913, no. 33: 2.

14 "Tygodnik Drohobycki” 1914, no. 4: 1.

15 Sefer zikaron le-Drohobycz, Boryslaw ve-ha-seviva 1959: 97. 
were obtained from voluntary donations, membership fees, and the staging of ticketed readings, shows and performances. ${ }^{16}$ The founding assembly elected Jakub Feuerstein as the first chairman. ${ }^{17}$ An important element of the statute was cooperation with the Jewish commune, which is understood as presenting all reports to the commune for approval. Any surplus income was transferred to the Jewish community to establish a fund to maintain the home. In the event of the dissolution of the association, all property was transferred to the Department of Jewish Orphans. ${ }^{18}$ In the mid-1920s, ambiguities around the institution's property rights began to increase, which contributed to the conflict within the Jewish community. This was when the kahal lost its monopoly on Jewish charity. Moreover, the inheritance of the association in the event of its dissolution was to go directly to the Orphans' Home, and not to the Jewish Community as usual. The beginning of the 20th century is therefore the beginning of the capitalist model of charity in Drohobych.

Józef Matzis, BSc Eng., director of the Galicia Oil Company and a group of people decided to create the Jewish House of Orphans association, which claimed the rights to movable and immovable assets and to manage the home. The signatures of the 21 founders of the association were collected, which gave rise to a conflict with the religious community, which maintained its rights to property ownership at Sobieskiego Street. Information on the broader context of the dispute is provided by the surviving letter of the Jewish Community's submission to the Ministry of Enlightenment and Administration and the Poviat Eldership, which presents arguments confirming the orphanage to be the property of the Jewish community in Drohobych. It also informs that the late Eliasz Feuerstein and Jakub Freuerstein were the superiors of the community and initiated the creation of the house, although the only owner and manager was the community. He also describes the enormous effort made by members of the commune to create and maintain an initiative relevant to the community. From 1906, the commune made preparations to build a house for orphans. At that time, a special fund was established at the local Savings Bank, collecting funds for this purpose, and as early as 1908 and 1910 land for construction was purchased. At the beginning of 1917, the religious council appointed an endowment fund that would assure the ongoing financing of the home's needs. It was feared that the accumulated funds would not be enough for self-financing. An initiative was taken up in the hopes that the accumulated capital would at least partly cover the needs of the home's pupils. The municipality's submission asked a number of private individuals and companies to make a contribution to Jakub Feuerstein or the municipality's submission. Many Drohobychans and people who had businesses there were permanently living in Vienna, but their relationship with the city and the Jewish community was strong. An account was created for them at the Teltscher \& Weidholz Banking House in the 9th district of Vienna, where they could make donations to the orphans' home. ${ }^{19}$ The endowment fund amounted to approximately 1.5 million crowns, of which the largest contributions were made by three oil companies: Galicja (100,000 crowns),

\footnotetext{
16 DALO, Fond 1, desc. 53, case 275: 5.

17 Ibid.: 4.

18 Ibid.: 5-7.

19 Ibid.: 15.
} 
Austria (10,000 crowns) and Karpaty (12,000 crowns). ${ }^{20}$ The building's equipment was covered by funds collected among members of the commune, supporters of the initiative, and with the support of the municipalities of Drohobych, Boryslav and Tustanowice. ${ }^{21}$ To encourage donations, it was decided to honor the donors by displaying their names on boards in the lobby of the building, dividing them into three categories depending on how much they contributed: benefactor founders (over 10,000 crowns), founders (over 2,000 crowns) and donors (up to 2,000 crowns).22 The vast majority of donors were men, as only eight out of the 55 names mentioned were of women.

The dispute over ownership and the right to manage the facility lasted several years amid an atmosphere of scandal and mutual accusations. An agreement was reached only in 1927, and its contents are given in different versions, which only complicates the reproduction of events.

The institution's income came from the land, prayer houses, city subsidies and interest-bearing savings. The self-sufficiency of the association, assumed at the beginning, whose main security would be the endowment fund, could not be assured. Over time, expenses exceeded income and donations to the orphanage. In the mid-1920s, the financial situation deteriorated, and some donors, such as the American Jewish Joint Distribution Committee, stopped funding, probably because of a conflict over the right to the property. Short-term charity activities were initiated at that time to raise funds to keep the Orphans' Home open. For example, a Week of Jewish Orphans was organized, during which volunteers canvassed city residents in their homes asking for contributions. ${ }^{23}$ Similar fundraising was organized at the facility through various games and parties such as "Great Garden Fun," football matches, theatre performances, dances, and New Year's balls. ${ }^{24}$

The pupils developed their talents in classes and after-school activities and ceremonies in which they eagerly participated; for example, on the occasion of the name-day ${ }^{25}$ of Marshal Piłsudski, children recited poems. ${ }^{26}$

20 Ibid.

21 DALO, Fond 1137, desc. 1, case 302: 8-9.

22 The tables included the following names: Founders: Mozes Gartenberg, Wilhelm von Offenheim, W.H. Mac Garvey, Ettel Euerstein, Jakób Feuerstein, Adela Feuerstein, Gmina Tustanowice, Markus Seeman, Oskar von Szimnaj, Joachim Sternbach. Founders: Jonasz Kuhmerker, Sabina Kuhmerker, Schulem Schreier, Ignacy Gertenberg syn Mojżesza, Dawid Gartenberg, Berta Gartenberg, Spadkobiercy Izaka Steuermana, Aba Spitzman, Rachela Spitzman, Aron Spitzman, Rebeka Spitzman, Jakób Spitzman, Charlotte Spitzman, Chaje Chajes, Ignacy Gartenberg syn Lejzora, Józef Gartenberg, Dawid Hartenstein, Markus Steuerman, Ignacy Feuerstein, Dr Marceli Fraenkel, Adolf Kiesler, Marceli Schreier, Józef Diamantstein, Mozes Diamantstein, M.H. Erdheim, Hersch Mendelsohn Eliasz, Ellenberg, Dr Arnold Segal, B. Józef Sussman, Lipa Suchestow, Dr I. Taubenfeld, Dr Aleksander Bergwerk, Lipa Bergwerk, Bronisław Rappaport, Adolf Hermelin, Zygmunt Klarfeld, Lipe Tannenbaum, Jakób Kammerman, H.B. Bloch, Samuel Weinstock, Salomon Rothenberg, Lejzor Rothenberg, Adolf Rothenberg, Eliasz Spitzman, Abraham Leib Schreier, Abr. I. Kurmann. Fundatorzy: Imre Pirnitzer. Chwila 1927, no. 2574 (2874): 13.

${ }^{23}$ Chwila 1924, no. 2065: 7.

24 An example of admission to a garden play cost an adult 1 złoty, a child 50 groszy. Głos DrohobyckoBorysławsko-Samborsko-Stryjski 1930, no. 14: 3; Chwila 1924, no. 1925: 6; no. 2045: 5; Chwila 1925 , no. 1141: 6; no. 2092: 5 .

${ }_{25}$ Name day - a custom from the Christian tradition consisting in celebrating the day of the year associated with a first name. The list of names is linked to the liturgical calendar. The celebration is similar to a birthday.

${ }^{26}$ Głos Drohobycko-Borysławsko-Samborsko-Stryjski 1934, no. 4: 2. 
In the mid-1920s, an irradiation station was installed in the orphanage, thanks to which patients from the region had access to a quartz lamp in Drohobych without having to travel to Lviv. The revenues thus obtained were used to support the Jewish orphans. ${ }^{27}$

In 1917, an interim board of three women, Sala Arztowa, Anna Bauerowa and Fela Suchestow, submitted the statute of a Jewish school for girls to the Imperial Governorship in Lviv. ${ }^{28}$ The primary goal of the association was to collect funds for establishing, equipping, and maintaining a Jewish school for girls living in poverty. Funds for this purpose were obtained from ticketed concerts, festivities, theatre performances, and voluntary donations in addition to subsidies and foundation donations. The first attempt to found an association encountered administrative and legal problems. Pursuant to the official remarks, the unclear statutory wording was clarified: therefore, the school was to provide girls aged 4-7 with daily care (it was not a boarding school), to maintain and raise them, and provide age-appropriate instruction in Polish. ${ }^{29}$

Members of the association were divided into ordinary members, those adopted by the General Meeting and paying at least 12 crowns a year, and honorary members, for those distinguished in their activities for the association, and founding members, people who showed physical or moral support to the home or made a single donation of 300 crowns. ${ }^{30}$ Similarly to other associations, the Department, the Audit Committee and the Management Board dealt with statutory activities, while more important decisions were made during the General Meeting. The "Jewish School" Association survived the First World War and geopolitical changes. Those most active in the work of the association were women, usually the wives of prominent citizens of Drohobycz, doctors, lawyers, and oil workers, who in their free time engaged in charitable activities for the benefit of the Jewish community.

In the interwar period, the school was extremely active. It expanded the age range of the target group, and also raised funds for the construction of a new headquarters, because the first was in the city centre, too far from the Jewish quarter to meet its statutory assumption of helping poor Jewish children. The new headquarters at 22 Polna Street served as a school from 1925. The cost incurred was not very high in relation to the value of the property, because half of the building was bought thanks to the efforts of the board and Wilhelm Ruhrberg, while the other half belonged to the foundation of the late Mrs. Schleierowa. The opening of the new headquarters was celebrated to the best of its financial capabilities, quite modestly, as after the house was dedicated prayers were said and "Hatikva" was solemnly sung. ${ }^{31}$

Dozens of young people who were looked after by the association were provided with all-day care, several meals a day, clothing, and medical care. The members of the school were constantly organizing cultural meetings, festivities, and games in order to raise funds for statutory activities In 1925, they held costume parties for children over the age of three, amateur theatrical performances, festivals, and others. ${ }^{32}$

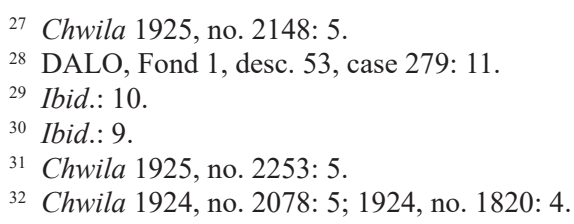


The Jewish orphanage was one of the thriving charity organizations in Drohobych, and at the beginning of the 1930s a foundation stone was laid for a new building of their own, which was located in the centre of the Jewish district, in Doktor Reicha Street. The ceremony was honoured the Mayor of Drohobych Rajmund Jarosz and Rabbi Awigdor, who gave a speech in Polish and Hebrew. Many people contributed to the creation of the new headquarters, and assisted the Society in its activities, for example, an engineer named Goldwasser carried out the project for free and supervised its construction, and the land was donated by the Jewish Community. Despite the enormous support, the construction costs far exceeded the company's financial capabilities, putting it in debt. Subsidies received from the Jewish Community did not meet their needs. Although the difficulties were not over, the society operated until the end of the war. In 1938 it sent children to a day camp during which they received four meals a day and did gymnastics and played games, all thanks to subsidies received from among others the Municipal Committee for Helping Children and Youth in Drohobych, the Central Committee for the Care of Orphans in Lviv, the Jewish Religious Community in Drohobych, and the Society for Combating Tuberculosis. ${ }^{33}$

The functioning of the society would not have been possible without private donations, which occasionally funded the organization's budget. One such form was through inheritance, and in this way the Jewish orphanage acquired from the late Sarah Schreierowa the deed to half the house in which it had previously been based. ${ }^{34}$

Just before the outbreak of World War II, the orphanage looked after 63 orphans aged four to thirteen who received three meals a day, clothing, and medical care. The annual budget of 8,000 Polish zloty was mostly covered by membership fees. ${ }^{35}$

One of the Jewish families that became part of the city's history and whose Jewish community owed hospital care was the Gartenberg family of oil industrialists. The first modern city hospital in Drohobych was built in 1831, but it did not meet the needs of the local community. The Jewish community had its own hospital, which was recorded in the book of Josephine after cadastral number 2173 as a kahal hospital, located in the Łan district, near the Great Synagogue. It probably lacked the capacity to meet the needs of many patients. Thanks to the financial commitment of Mojżesz and Otylia Gartenberg, a modern, well-equipped Jewish hospital with only 18 beds was built in the second half of the 20th century. ${ }^{36}$ The actual participation of the Gartenberg family in financing the hospital remains unclear, as according to the hospital's inaugural speech in 1860, Selig Lauterbach and Osias Sternbach were also founders. ${ }^{37}$ The 1928 Jewish Community Superiority report states that the hospital was founded in 1898 by the Gartenbergs. ${ }^{38}$ The differences also concern the size of the hospital; for example, a book describing the history of medicine in Drohobych gives a smaller number of beds, only $12 .{ }^{39}$

33 Chwila, wyd. wieczorne 1938, no. 1224: 10.

34 Chwila, wyd. wieczorne 1938, no. 1144: 10.

35 Chwila, wyd. wieczorne 1938, no. 1307: 10.

36 Pilat 1913: 150; Sefer zikaron le-Drohobycz, Boryslaw ve-ha-seviva: 98.

37 Segal 1860: 10.

38 Sprawozdanie Przedłożeństwa Żydowskiej Gminy Wyznaniowej w Drohobyczu za czas od 19 czerwca 1924 do 19 czerwca 1928, 1928: 16.

39 Богаченко, Романяк 2008: 19. 
The Gartenberg family founded a foundation named after Mojżesz and Otylia, who spent their time between Vienna and Drohobych. In particular, Otylia Gartenberg's charity activity was praised by the non-Jewish press. The author of an article in Kurier Drohobycki describes her concern for the victims, not specifying the origin of the people she helped. It can be assumed that Otylia's activity went beyond the Jewish community. ${ }^{40}$ Their descendants, about whom we learn from archival and press documents of the interwar period in connection with unregulated matters of inheritance of the property, lived permanently in Vienna. Unfortunately, the exact foundation activities of the Gartenbergs cannot be traced, but it is known that in 1888 their home and financial support built the Old People's Home in Mickiewicz Street. The Gartenbergs put aside an additional 100,000 zł for its maintenance. The house was a haven for the elderly, and it had a cultural and religious function. With the outbreak of World War I the building began to deteriorate, and it continued to such an extent that in the 1920s the legal situation of the Old People's Home had to be regulated and urgent renovation measures taken. ${ }^{41}$ Thanks to a waiver of the rights of the Gartenberg heirs, the Jewish community, which financed the functioning of the house, could continue renovation works of the entire building in order to serve as many people as possible. The Old People's Home also served as a cultural and educational facility as well as a religious centre, with its own prayer room and Judaic library. ${ }^{42}$

At the beginning of the 20th century, the Jewish community was struggling with many administrative and legal problems, such as the above-mentioned conflict over the orphanage. Thanks to the intervention of the members of the kehilla, the Jewish hospital was also taken over from the Gartenberg family, which was fully financed by the kehilla and served the poorest who could not be hospitalized in the municipal hospital.

In 1883 Jewish women created by edict the Israelitischer Frauenverein Association in Drohobych, approved by the Governorship. The association also continued its activity through the interwar period. The history and nature of its activity is impossible to reproduce, and it serves as a good example of the troubles encountered by the historian when trying to explore the charitable activities of the Jews in Drohobych. In 1919 the board of the association sent to the governorship in Lviv a request for a copy of the statute, after the one in Drohobych was lost in the hostilities. The governorship responded negatively to the request because its office had lost the statute. In this situation, a new statute of the association was drawn up, but formal registration did not take place until 1923. In the interwar period it operated under the name "Association of the Charity of Jewish Ladies." ${ }^{43}$ Ernestyna Alterowa became the first chairwoman, and she made efforts to put the association's status into order. ${ }^{44}$ The main goal of the association was to support Jewish obstetricians and impoverished Jewish patients. Similarly to the statutes of other charity associations, the organs were the management board, the general meeting, the audit commission, and the department. For example, the faculty consisted of the chairwoman, her two deputies, a secretary, a treasurer, and twenty members elected by

\footnotetext{
40 Moskalets 2013: 88.

41 Sefer zikaron le-Drohobycz, Boryslaw ve-ha-seviva: 98; Chwila 1926, no. 2562: 8.

${ }^{42}$ Chwila 1930, no. 3878: 11.

43 DALO, Fond 1, desc. 53, case 278: 22-23.

44 Ibid.: 21.
} 
the General Assembly. Anyone of good repute approved by a vote of the general meeting could become a member of the association. A member's duties included paying the membership fee, observing the statutory provisions, and supporting the association with to the best of her or his abilities. ${ }^{45}$ The name of the association clearly suggests women's participation, but the statute did not limit participation in the association's activities on the grounds of gender. An analysis of the composition of the board over twenty years shows that the decision-makers were women, but unfortunately the list of all members of the association is missing. Ernestyna Alterowa presided over the association until 1937, according to the last official notification of the composition of the board. ${ }^{46}$

A similar association had the task of looking after patients in the hospital was founded at the end of the 19th century by Benoth Jeschurim (Töchter Jeschurims). It survived the turmoil of war and was still active in the 1930s. As it did not have its own premises, statutory meetings were held in the apartment of the Rabbi's wife Malki Panzerowa in Borysławska Street. ${ }^{47}$ The association was financed by the Jewish commune. This is another example of an attempt to recreate the activities of the association in Drohobych based on several pages of archival documents. There were more such associations.

The scope of the charitable activity of Jews in Drohobych at the beginning of the 20th century is difficult to estimate, both in terms of the number of associations and their size. Above are the results of the query in the Ukrainian peripheral archive, which has an extensive resources to study the history of Jews in Drohobych. The documentation obtained does not exhaust the topic of Jewish charity in Drohobych until World War I, as it is only a fragment of the activity which has been confirmed in archival sources. The resource analysis indicates the need for further research in this area. It also illustrates the problems encountered by historians attempting to describe the history of the Jewish communities of the smaller towns of former Galicia. Ukrainian archives contain much fascinating information, although exploring them is extremely difficult. The above descriptions of charity activities are only a fragment, because, as already mentioned, they do not include religious and charity associations, or activities carried out by the city for the poor and needy. It is worth noting the carelessness of officials and activists while keeping records of associations. The re-registration process itself lasted several years, as exemplified by the situation of the Israelitischer Frauenverein Association described above. Most of the information is thus held in statutes and their copies, as in principle they document the correspondence with governorship, the Provincial Office in Lviv and the poviat starosty (district head) in Drohobych. They constitute a very rudimentary formal record of the associations' activities, making them a poor source of information. In addition, some documents did not survive as a result of cluttered offices and the ravages of war. For the most part, only the goals and main assumptions of the associations are possible to discern. A little more information can be found in the archives of the interwar period, but they too are full of blank spots.

A survey of the local press partly helps to reconstruct the history of charity, although they should be approached very carefully. Incorrect information and wrong names were repeatedly published, complicating the historian's work.

\footnotetext{
${ }^{45}$ Ibid.: $23-24$.

46 Ibid.: 32.

${ }^{47}$ DALO, Fond 1, desc. 53, case 204: 16.
} 
The development of the oil industry affected many areas of Jewish activity in Drohobych, including charity. Unfortunately, we currently lack many resources documenting this activity, so we rely on residual information. Detailed documentation of individual organizations probably disappeared during the two world wars. The magnificent buildings funded for the benefit of the Jewish community often served various armies as barracks and military hospitals. Undoubtedly, the development of industry had an impact on the development of charity among the Jewish community. Institutions had been built over the years to serve the poor of all ages. The impressive buildings survived the wars and serve the Ukrainian community to this day. Their durability is testament to the longterm planning of assistance to the poorest, as well as their being provided with good material conditions. In addition, the mentioned organizations with their own headquarters contributed to the development of cultural life by functioning as centers of education and culture. From the city authorities' point of view, independent charities financed from private funds were undoubtedly welcome. The city of Drohobych was obliged to help the poor and needy residents, so private charity activities relieved the city's budget. Knowing exactly who needed material or other forms of support meant that their actions brought about measurable results.

Against the background of aid organizations, one can distinguish the activities of Jewish women from the middle class, especially for the benefit of poor children and young students. Analysing the charitable activities of Jews in Drohobych over a wider time frame, the same names of female activists, who were the wives of doctors, lawyers, industrialists, and other prominent men, appear in many associations. It would be extraordinary to examine the documentation of the Gartenberg Foundation, the founders of the hospital and the old people's home, because these were certainly not their only acts of charity.

There is also quite a large group of religious societies, one of the assumptions of which was mutual assistance within the association. They can be placed in the religiouscharitable category due to statutory assumptions. The author decided not to include them in this article because in her opinion they were more religious, and their charity resulted from religious principles rather than a real desire to help groups of people who needed it. In addition, financial or moral assistance depended on their membership in an association, in contrast to the charities considered above, which helped people regardless of their religious involvement. In addition, these organizations were not associated with any place of worship, which is characteristic of religious and charitable associations. The only point of contact was funding by the Jewish community to varying degrees and during different periods of their activity. In a sense, the Jewish community was the guarantor of their activity, as a unit serving Jews without distinguishing their religious or political involvement.

It should be remembered that at the beginning of the 20th century, Drohobych was still a developing, unstable city, and in a very short time it transformed from a small town into the centre of the oil basin. It was closely associated with the surrounding cities, such as Borysław, where oil production was concentrated. The problems of the oil industry had a powerful influence on the condition of the inhabitants. At the end of the 19 th century, the increase in poverty was caused by the massive lack of employment for 
Jewish workers in Boryslav. ${ }^{48}$ This trend was also followed by the Jewish community of Drohobych, partly not ready to receive the masses of visiting workers who did not intend to tie themselves to the city but were only concerned with the black gold flowing out of the ground. It was a community not ready for human dramas of a higher intensity than ever before, a dynamically changing reality in which many people found it difficult to live. It is therefore a challenge to assess to what extent Jewish charitable organizations responded to the demand. It seems it was insufficient despite all their efforts. An analysis of the activities of the associations indicates a growing group in need of support. At that time, no further records of the fate of the pupils were kept, and this would greatly facilitate the assessment of the charity dimension. The Jewish Orphanage changed its place of business twice, while increasing the scope of its assistance. Most organizations sought to build or purchase property in which they could operate. Their financing came from several sources, including the Jewish community, and this allowed them to overcome any financial difficulties. These are the main reasons for which the associations survived the war and could continue their activities in the Second Polish Republic, unlike other organizations that operated in a less formal way, without their own separate establishment. It is easier to raise funds for organizations whose finances and activities are clear and coherent, and above all tangible. Poor Jewish children and orphans received material support from various organizations in the form of meals, but above all education, which was not limited to religious education. The classes in the orphanage were conducted in Polish, which provided the juveniles with a better start in life, and more opportunities to get a better job than children from poor families with many children who, after completing basic education, had to take any job available to help support their parents. The rapid industrialization of the vicinity of Drohobych, as well as the enrichment of Jews in the context of oil extraction, led to an increase in local philanthropy aimed at the Jewish community. Social changes, new ideologies, and a lack of labour regulations meant that the masses found themselves in a new and very difficult reality, and organized charity was a response to the new challenges.

Many organizations were formed spontaneously and just as spontaneously fell apart, and some of the charity activity was irregular and informal, which significantly limits the possibility of presenting the full range of charity activities in Drohobych at the beginning of the 20th century. Established in the nineteenth century, the associations described above performed the functions of social care, comprehensively taking care of the needy from Drohobych and the surrounding area. Nevertheless, a very important aspect of the various charitable activities in the Jewish community is the beginning of the activities of philanthropists from Drohobych, who focused on local aid. Although their institutions supported the Jewish community, conflicts sometimes ensued, and with them divisions within the Jewish community. This perfectly reflects the moment of departure from traditional forms of charity concentrated in the Jewish community to more modern capitalist forms and a temporary strengthening of the position of philanthropists. Another important aspect of the charity work in Drohobych is the growing activity of women who were, for example, among the founders of the Jewish Orphanage. Less wealthy women

\footnotetext{
${ }^{48}$ Moskalets 2014.
} 
founded aid societies on their own: some of them resisted the war and the geopolitical turmoil, helping those in need.

Operating at the turn of the century and at the beginning of the twentieth century, the above-mentioned charities continued, developing care for the poor and needy despite financial difficulties, World War I, and the change from Austrian rule to the Polish Republic. World War II brought about the end of philanthropic activities in the Jewish community.

\section{ABBREVIATIONS}

DALO - The State Archives of Lviv Oblast

\section{BIBLIOGRAPHY}

\section{Archival sources}

DALO

Fond 1, desc. 53, case 204, 275, 279.

Fond 1137, desc. 1, case 302 .

\section{Press}

Chwila 1924, 1925, 1926, 1927, 1930.

Chwila, wydanie wieczorne 1938.

Gtos Drohobycko-Borysławsko-Samborsko-Stryjski 1930, 1934.

Tygodnik Drohobycki 1913, 1914.

\section{Primary literature}

Cała, A. (2003), Ostatnie pokolenie. Autobiografie polskiej młodzieży żydowskiej okresu międzywojennego ze zbiorów YIVO Institute for Jewish Research w Nowym Jorku, Warszawa.

Sprawozdanie Przedłożeństwa Żydowskiej Gminy Wyznaniowej w Drohobyczu za czas od 19 czerwca 1924 do 19 czerwca 1928 (1928), Lwów.

\section{Secondary literature}

Богаченко, М., and М. Романяк (2008), Медицина Дрогобича, Дрогобич.

Broński, K. (2008), Kwestia opieki publicznej nad ubogimi w Galicji w dobie autonomicznej (wybrane problemy), Zeszyty Naukowe Uniwersytetu Ekonomicznego w Krakowie, no. 779: 9k-27.

Domańska, J. (2011), Dobroczynność względem sierot na ziemiach polskich do 1918 roku, Biuletyn Historii Wychowania, no. 27: 19-31.

Frank, A.F. (2005), Oil Empire. Visions of Prosperity in Austrian Galicia, Cambridge, MA.

Hakehillot. Encyclopedia of Jewish Communities, Poland, vol. 2 (1980), Jerusalem.

Лазорак, Б.(2013), Будинок для єврейських сиріт імені Франца Йосифа І в Дрогобичі (1912 - 1914 pp.): мафіозний піар чи милосердна фундація Якуба Файєрштайна?, in: Актуальні питання гуманітарних наук: міжвузівський збірник наукових праць молодих вчених Дрогобицького державного педагогічного університету імені Івана Франка/Редактори-упорядники В. Ільницький, А. Душний, І. Зимомря. - Дрогобич, Вип. 6: 33-51.

Meissner, A. (red.) (2002), Opieka nad dzieckiem w Galicji, Galicja i jej dziedzictwo, vol. 16, Rzeszów. Moskalets, V. (2014), The Exodus from Galician Mitsraim: The Unemployment of Jewish Workers in Boryslav and the Rescue Campaign of 1897-1899, Scripta Judaica Cracoviensia, vol. 12: 59-68. 
Moskalets, V. (2015), Analiza sieci przedsiębiorców naftowych w roku 1096: rola przedsiębiorców żydowskich w rozwoju zagłębia Borysławsko-drohobyckiego, in: O Drohobyczu, trójmieście i zagtębiu. Polsko - ukraińskie studia z socjologii historycznej, Rzeszów.

Москалець, В.К. (2013), БЛАГОДІЙНА ДІЯЛЬНІСТЬ ЄВРЕЙСЬКИХ ПІДПРИЕМЦІВ ДРОГОБИЧА І БОРИСЛАВА ЯК ІНДИКАТОР МОДЕРНОСТІ, in: Вісник Національного технічного університету “ХПІ.” Сер.: Актуальні проблеми історії України, по. 25: 86-93.

Mściwujewski, M. (1929), Królewskie Wolne Miasto Drohobycz, Lwów-Drohobycz.

Pilat, T. (1913), Podręcznik statystyki Galicji, vol. 9, part 1, Lwów.

Pollack, M. (2007), Po Galicji, Wołowiec.

Polski Stownik Judaistyczny. Dzieje-Kultura-Religia-Ludzie (2003), vol. 1, Warszawa.

Rosenberg, M. (1938), Żyd pierwszym wynalazcą destylacji ropy, in: Almanach i leksykon żydostwa polskiego, vol. 2, Lwów.

Schipper, I. (1937), Dzieje handlu żydowskiego na ziemiach polskich, Warszawa.

Sefer zikaron le-Drohobycz, Boryslaw ve-ha-seviva (1959), ed. N.M. Gelber, Tel-Aviv.

Segal, J. (1860), Gelengenheitsrede bei Einwahung des israelitischen Krankenhaus in Drohobycz am 8 Mai 1860, Lemberg.

Szczepanowski, S.A. (1888), Nędza Galicji w cyfrach i program energicznego rozwoju gospodarstwa krajowego, Lwów.

Tomanek, L. (1928), Ignacy Łukasiewicz. Twórca przemystu naftowego w Polsce. Wielki inicjator wielki jatmużnik. W 75-tą rocznicę zapalenia pierwszej lampy naftowej, Miejsce Piastowe.

Tyloch, W. (1987), Judaizm, Warszawa.

Wikler, J. (1969), Z dziejów Żydów w Drohobyczu, Biuletyn Żydowskiego Instytutu Historycznego, no. 71-72. 